
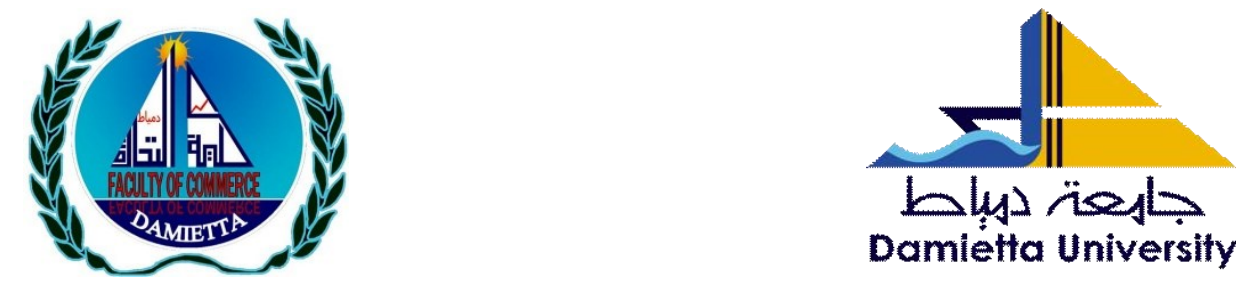

\title{
Digital Transformation as a Stimulator for Maritime Competitiveness: A Suez Canal Case Study
}

By

\section{Dr. Khaled Abdallah El-Sakty}

College of International Transport and

Logistics - Arab Academy for Science, Technology and Maritime Transport

(AAST) - Cairo branch- Egypt khaled.sakty@aast.edu

\author{
Dr. Ahmed Mohamed Ezzat \\ College of International Transport and \\ Logistics - Arab Academy for Science, \\ Technology and Maritime Transport \\ (AAST) - Cairo branch- Egypt \\ ezatahmed@aast.edu
}

Scientific Journal for Financial and Commercial Studies and Researches (SJFCSR)

Faculty of Commerce - Damietta University

Vol.2, No.1, Part 1., Jan. 2021

\section{APA Citation:}

El-Sakty, K. A. and Ezzat, A. M. (2021). Digital Transformation as a Stimulator for Maritime Competitiveness: A Suez Canal Case Study. Scientific Journal for Financial and Commercial Studies and Researches (SJFCSR), Vol.2 (1) Part1. pp. 599-642.

Website: https://cfdj.journals.ekb.eg/ 
Scientific Journal for Financial and Commercial Studies and Researches

Dr. Khaled El-Sakty and Dr. Ahmed Ezzat

\begin{abstract}
Digital Transformation (DT) became very crucial issue in the business world with major impacts on any of its sectors. In a maritime context, applying digital technologies can help achieving sustainability goals and gaining a competitive advantage through reducing costs, enhancing efficiency and improving environmental protection. Theoretically, few studies described the effects of DT on maritime competitiveness. In this paper, the channels through which DT is transmitted to influence competitiveness based on service quality are identified and a survey is used to study how DT can contribute to affect the quality of maritime services of the Suez Canal. The results highlighted the significance of DT in affecting maritime competitiveness in the Suez Canal through affecting processes, management, outcomes, resources and image. Results stressed on the need for directing Suez Canal authority to more focus on investing in physical infrastructure and human capital to accelerate the transformation towards automated and smart procedures.
\end{abstract}

Key Words: Competitiveness, Digital Transformation, Maritime transport, Quality of maritime services, Suez Canal 
Scientific Journal for Financial and Commercial Studies and Researches

Dr. Khaled El-Sakty and Dr. Ahmed Ezzat

\section{Introduction}

Globalization is based on the need to facilitate the flow of trade (Lun et al., 2016). Trade facilitation means reducing the costs of trade-related operations and increasing their efficiency. This led to the use of trade facilitation as a global development tool. Accordingly, it has become among the top concerns of international organizations such as the International Maritime Organization (IMO), World Trade Organization (WTO), World Customs Organization (WCO), United Nations Centre for Electronic Business and Trade Facilitation (UN/CEFACT) and the International Federation of Freight Forwarders Associations (FIATA).

The quality of maritime transport is essential for trade facilitation as over 90 percent of the volume of world merchandise trade is carried by a maritime transport. Hence, improving the quality of a maritime transport can help reducing transportation costs and the complexity of maritime operations (Babica et al., 2020). Additionally, it can support the safety and security of operations.

About $50 \%$ of the shipping costs in the global container shipping industry can be traced back to the time spent on the paperwork (Babica et al., 2020). Hence, with its high degree of maritime connectivity and its large number of interfaces, improving the quality of maritime services and competitiveness requires a broad range of applications for digital technologies. The use of DT in maritime services can lead to reducing costs, enhancing efficiency through optimizing the fleet controls, supporting security through avoiding critical situations, reducing the danger of accidents, and improving environmental protection. This helps in achieving sustainability goals. Besides, DT became an important driver in upgrading and improving the quality of maritime services. Accordingly, it can be considered as a source of gaining a competitive advantage. 


\section{Scientific Journal for Financial and Commercial Studies and Researches}

\section{Dr. Khaled El-Sakty and Dr. Ahmed Ezzat}

In 2018, Egypt ranked $18^{\text {th }}$ out of 157 countries in UNCTAD's "Liner Shipping Connectivity Index" (LSCI). It is ranked the $3^{\text {rd }}$ in MENA region and the $2^{\text {nd }}$ in the South Mediterranean region (SRM, Alex Bank, 2018). Despite the significant improvement in the LSCI index, Egypt is not commensurate with its capabilities in the region, compared with other countries within the MENA region, such as Morocco and UAE. Accordingly, Egypt needs to focus its investment in the maritime sector on improving shipping connectivity to improve the country's position in international trade.

The Suez Canal (SC) share is about $8 \%$ of the world seaborne trade, about $24.5 \%$ of the world container trade, about $9 \%$ of the world's seaborne oil trade together with the SUMED Pipeline, and about $9 \%$ of the world's LNG trade (SRM and Alex Bank, 2018). In the line with SC authority's vision, the authority is facing the pressure to become smarter and digitally-enabled to improve how it interacts and transacts with customers and competitors. Focusing on a maritime connectivity, SC authority can turn this potential threat into an opportunity through achieving true DT.

Therefore, this paper aims to study how DT can contribute a positive effect on maritime competitiveness that is based on service quality provided by SC Authority. An exploratory approach has followed through surveying the case study; with a target population of around 471 navigation agents that are served by SC authority. This helps to study in-depth the role of the DT and how it can contribute positively effect on the quality of service in the maritime services domain. 


\section{Scientific Journal for Financial and Commercial Studies and Researches}

\section{Dr. Khaled El-Sakty and Dr. Ahmed Ezzat}

The rest of the paper is organized as follows: the second section discusses relevant literature to reach the research gap and constructing research hypotheses. The third section illustrates the research methodology including the construction of the survey and case study selection. The fourth section represents the empirical results. Policy implications, conclusions and recommendations are addressed in section five.

\section{Literature Review}

This section reviews the conceptual review, digital trends in the maritime services domain, quality of maritime service effects on trade facilitation and DT as a source of gaining competitive advantage in maritime service. Then, the section ends up with stating the research gap and constructing the research hypotheses.

\subsection{Conceptual Review}

This section is concerned with the definition of the basic terms used, namely DT and technologies framework in maritime services and service quality models.

The DT is described as the deep and accelerating transformation in business in particular and society in general to achieve the full use of changes in digital technologies in addition to the associated changes in the communication of organizations, individuals and objects to improve performance by improving existing business processes, exploring new sources of revenue and ensuring sustainable value creation (Babica et al., 2020; Gartner, 2016; Gimpel et al., 2017; Wade, 2015). Bloomberg (2014) defined a DT as any form of new investment or realignment of technology and business models to further stimulate digital customers more efficiently at every point of contact in the customer experience lifecycle. 


\section{Scientific Journal for Financial and Commercial Studies and Researches}

\section{Dr. Khaled El-Sakty and Dr. Ahmed Ezzat}

These definitions refer to DT as a powerful and versatile transformative tool for all kinds of activities such as financial services, science and innovation, transportation and logistics. Within organizations, this process goes beyond the automation of existing activities to encompass redesigning and innovation of work processes and practices and of the organizations that carry them out. It also involves a dramatic increase in the generation and use of digitized data to analyze the social and natural environment, monitor resources, understand clients and partners, coordinate actions, deliver services, measure performance, improve policy-making and secure citizen feedback almost in real-time.

The DT framework consists of three major layers: business, operations and infrastructure (Tijan et al., 2019). First, business DT refers to the redesign of the strategic position in the digital ecosystem, service portfolio and business models. Second, operational DT indicates the restructuring of the operating model and capabilities that enables effective execution of the future business models, through digitization of front-end capabilities including marketing, sales, services and Omni-channel interaction. Third, infrastructure DT points out a full reconstruction of ICT infrastructure including equipment, network service and operations (HUAWEI, 2016).

Technologies associated with DT include the five groups commonly abbreviated as SMACI: social, mobile, analytics, cloud and maritime internet of things. While these technologies are already in widespread use, new technological trends include artificial intelligence, 3D/4D printing and wearable, as well as augmented and virtual reality (Balakumar, 2014; Ey, 2016). 


\section{Scientific Journal for Financial and Commercial Studies and Researches}

\section{Dr. Khaled El-Sakty and Dr. Ahmed Ezzat}

The maritime industry is under rapid technological transformation, which is characterized by increased use of digital systems, smart sensors and networks for data transfer among stakeholders.

There is no standard definition for either of the terms "quality" or "quality of service" because they both have multiple dimensions (Chahal and Kumari, 2012). Various scholars have suggested several different quality of services models. The common dimensions of service quality included in most models are input ${ }^{1}$, interactive ${ }^{2}$, process $^{3}$, physical $^{4}$, outcome ${ }^{5}$, technical ${ }^{6}$,

${ }^{1}$ It points out the component of consumer's overall quality evaluations that includes consideration of physical elements and other production resources, both tangible and intangible such as equipment; facilities; employee appearance, knowledge, and skill used in producing the service.

${ }^{2}$ It refers to the dimension of quality originating in the interaction between the customer and the service organization such as the actual resources that the company uses to contact customers.

${ }^{3}$ The customer's qualitative evaluation of his participation in the service production process is based on how the customer sees the production process and how well he sees his role fitting into the process.

${ }^{4}$ The dimension of quality originating in the physical elements needed in a service production process.

${ }^{5}$ It refers to consumer's evaluation concerning the result of a service production process including items such as reliability, functional benefit, and emotional benefit.

${ }^{6}$ It captures the goodness of data transfer and data processing during the delivery of the electronic service. It subsumes several technical elements of the delivery process such as speed, responsiveness, privacy, and security. 


\section{Scientific Journal for Financial and Commercial Studies and Researches}

\section{Dr. Khaled El-Sakty and Dr. Ahmed Ezzat}

environmental ${ }^{7}$, delivery ${ }^{8}$, integration ${ }^{9}$ and virtual ${ }^{10}$ (Chahal and Kumari, 2012; Kiran and Singh, 2016; Thai, 2008).

Thai (2008) used the previously illustrated dimensions of service quality to develop and validate a measurement model to explore the concept of service quality in the maritime services domain. This model consists of six dimensions: resources, outcomes, process, management, image and social responsibility (ROPMIS). Hence, some elements are incorporated newly, such as management, image and social responsibility-related quality dimensions, which are critically important in the maritime industry. This research has adopted this model and reviewed the operational measurement elements of SC authority as a basis to support its maritime competitiveness based on these six dimensions of service quality.

\footnotetext{
${ }^{7}$ It refers to the dimension of quality that includes the effects of service production on varied characteristics of the ecosystems such as air and water purity, resource usage, noise and visual effects of buildings, and their potential effects on physical and mental health.

${ }^{8}$ It includes aspects that are relevant for the customers when they are looking for information, selecting from available options, or carrying out transactions.

${ }^{9}$ It includes items related to the consistency of content and process such as the degree to which a customer receives the same response to a query posed through different channels and the degree to which an interaction taking place through one channel takes into account eventual past interactions through other channels.

${ }^{10}$ The aspects of the service are automatically provided using virtual channels (e.g. the Web site) without human intervention. Virtual quality instruments should include efficiency (ease of use and speed), system availability, IT reliability and privacy of personal information about consumers.
} 
Scientific Journal for Financial and Commercial Studies and Researches

Dr. Khaled El-Sakty and Dr. Ahmed Ezzat

\subsection{Digital Trends in the Maritime Services Domain}

Based on the previous discussion, the maritime industry is undergoing a rapid technological transformation in light of its globalization and the intensity of competition in it, making it one of the economic sectors most in demand for DT.

The main technological transformation is divided into (Accenture, 2017; Adams et al., 2017; Babica et al., 2020; Kent et al., 2015):

- Digitalization of the shipping industry involves; automated shipbuilding, intelligent automation, digital twin, ship trials in the virtual world and digital thread.

- Digitalization of all maritime services comprises; sea traffic management, cloud computing in the maritime domain, robotics and autonomy, and the internet of services at sea.

- Digitalization of seaport operations includes; smart seaports, seaport community system, artificial intelligence, autonomous systems, integrated transport information system, e-navigation and internet of services at sea.

Heilig et al. (2017) divided the stages of technological transformation in maritime services into three basic generations, depending on the effects of the most important information technology and systems enablers on the maritime operations. The first generation (the 1960s - 1970s) involves the transformation to paperless procedures as a result of the development of containerization and intermodal transportation. This highlights the need for integrated transportation systems, which is supported by the development of Electronic Data Interchange (EDI). The second-generation (the 1990s - 2000s) 
Scientific Journal for Financial and Commercial Studies and Researches

Dr. Khaled El-Sakty and Dr. Ahmed Ezzat

includes the transformation to automated procedures in ports. The third generation (the $2010 \mathrm{~s}$ - now) is classified as the transformation to smart procedures targeting the integration of port infrastructure and traffic management to reach intelligent control of traffic and infrastructure depending on web and mobile applications. Despite this accelerating transformation towards digitalization of maritime operations, enhancing the efficiency of information exchange is required for data analysis targeting to increase the efficiency of decisions too quick response to changes and competition (Lun et al., 2016).

\subsection{Quality of Maritime Service Effects on Trade Facilitation}

The review of the available literature showed that there are main channels through which the quality of maritime services is transmitted to influence trade facilitation, namely the corresponding cost reduction leading to enhancing goods accessibility and the improvement in the quality of accompanying logistics services because of improving the efficiency of institution border factors (Munim and Schramm, 2018).

Despite trade costs are essentially unavoidable; improving the quality of maritime services can eliminate inefficiencies that can avoid excess costs. Among other things, the most effective types of trade costs that can be affected by improving the quality of maritime services are transportation costs, borderrelated costs and information and communication costs (Fink et al., 2005; Grainger et al., 2018). 


\section{Scientific Journal for Financial and Commercial Studies and Researches}

\section{Dr. Khaled El-Sakty and Dr. Ahmed Ezzat}

Transport and shipping costs often represent a binding constraint to international trade which sometimes exceeds the effects of tariffs and other trade barriers (Wilmsmeier and Hoffmann, 2008). This effect increases in the case of most developing countries as small countries, where they cannot influence the international prices of products (Azapmo, 2017). The study of UNCTAD (2013) stated that high transportation costs remain the biggest barrier to the least developed countries' trade competitiveness and equitable access to global markets. Thus, the increase in transportation and freight costs diminishes the profitability of international trade and thus reduces its competitive chances. To reduce transportation and freight costs, projects may retain a higher inventory of all stages along the supply chain, which entails more costs. The significance of these costs increases as the interest rate prevailing in the country increases. This highlights the importance of the role of improving the quality of maritime services in influencing time, shipping costs and the competitiveness of products (Friedt and Wilson, 2018; Hummels, 2007).

Friedt and Wilson (2018) used data on containerized trade and freight rates between the US, EU and Asia to test transportation costs' effects on trade volume. Results stated that a one percent permanent increase in transportation rates raises the average real freight rate leading to a reduction in the long-run volume of containerized trade by 0.058 percent. Additionally, the results highlighted that bilateral transport costs are endogenous in trade models. 


\section{Scientific Journal for Financial and Commercial Studies and Researches}

\section{Dr. Khaled El-Sakty and Dr. Ahmed Ezzat}

Kleinert and Spies (2011) highlighted that two main determinants affect the significance of transport and shipping costs in restricting trade facilitation. The first is the distance between locations. The second is the potential reduction in transport prices following the investment in more efficient technologies in transportation, which is affected by bilateral trade levels between the partners. Accordingly, Kleinert and Spies (2011) stated that transportation cost should be dealt with as an endogenous variable in trade models. Relying on data on trade of OECD countries with 61 partners provided by OECD ICTS database, the results confirmed that transportation costs are endogenous in trade models and that the increase in exports between partners by 10 percent is linked to a reduction in transport prices by 0.8 percent.

Regarding the border-related costs, they include all the costs generated from boarders related trade policy. Not only costs of importing increase as a result of trade-related border procedures, but the costs of exporting increase as well in the respective country (Sadikov, 2008). Thus, the increase in borderrelated costs reduces the profitability of international trade as well. To reduce border-related costs, it is proposed to rely more on the mechanization and digitization of border processes.

Sadikov (2008) used the gravity model approach to test the impact of border-related procedures on trade volumes in 140 countries in 2005, using both some signatures required for exporting and several procedures required to start a business. The results suggested that while registration procedures were not significant in affecting trade, signatures required has led to a reduction in exports by 4.5 percent. 


\title{
Scientific Journal for Financial and Commercial Studies and Researches
}

\author{
Dr. Khaled El-Sakty and Dr. Ahmed Ezzat
}

Azapmo (2017) examined the performance of cross-border trade costs in Pacific Island Countries (PIC) after the participation in regional trade agreements (RTAs). Cost, time and some documents to trade are used as performance indicators for cross-border trade costs for the period 2013-2017. The results show that border-related costs account for the largest share of the total cost of exporting and import in the majority of PIC countries. This cost amounted to 79 percent of the total costs in some cases. Consequently, the time taken to comply with borders is measured for more than two-thirds of the total time to trade. Accordingly, it is concluded that the existence of provisions to facilitate trade in RTAs is not sufficient to reduce cross-border trade costs. There is a need for supportive required policies such as support making trade facilitation reforms one of the essential components of both national trade policy and development plan and strategies.

Grainger et al. (2018) used a cost model to describe how can cost reduction enhances exporting trade. Two case studies are used in the application. The first concerns the United Kingdom's imports of meat from Mercosur countries. The second concerns Netherlands imports of flowers from Kenya. One of the key findings is the importance of border management and information and data sharing to facilitate the forms of trade in question.

Regarding the relative importance of information transaction, the transport costs has decreased with the increase in the pace of globalization, with the intensity of competition, and the need to improve the transparency of trade transactions (Epo and Nguenkwe, 2020; Meng, 2011). Consequently, information costs have become one of the important factors that need to be managed efficiently, relying on information and communication technology (ICT) and relationship network, to support trade facilitation (Fink et al., 2005; Grainger et al., 2018; Meng, 2011; Thiemann et al., 2012; UNCTAD, 2013). 


\title{
Scientific Journal for Financial and Commercial Studies and Researches
}

\author{
Dr. Khaled El-Sakty and Dr. Ahmed Ezzat
}

Various researches employed the gravity model approach to estimate the effects of ICT on supporting international trade (Epo and Nguenkwe, 2020; Fink et al., 2005; Thiemann et al., 2012). Fink et al. (2005) used aggregate bilateral trade and trade in different categories of products for the year 1999. The information and communication costs are described using per-minute bilateral calling prices charged in partners and calling price of each partner to the United States as one of the main destinations worldwide. The coefficients of these proxies are found to be negative and statistically significant in affecting both aggregate bilateral trade and trade in different categories of products.

Epo and Nguenkwe (2020) studied the impact of ICT development on encouraging intra-regional trade in ECOWAS countries over the period 1994 to 2014. The results stress the significance of ICT development in supporting intra-regional trade.

Thiemann et al. (2012) studied the effects of ICT on supporting international trade of fruit and vegetables between trading partners, which represents at least 90 percent of world trade for each product for the period 1995 to 2009. Levels of internet, fixed telephone usage and mobile phone penetration are used as proxies for levels of information and communication technology to explain the value of trade in the gravity model. The results found that the three proxies are significantly affecting trade values for most fruit and vegetables. 


\section{Scientific Journal for Financial and Commercial Studies and Researches}

Dr. Khaled El-Sakty and Dr. Ahmed Ezzat

Nath and Liu (2017) used GMM and panel data fixed effects approaches to examine the effects of ICT on trade-in ten major service items relying on data for 49 countries between 2000 and 2013. An ICT development index was constructed to capture three dimensions of technology including access, use and skills. The results confirmed that ICT development is one of the significant determinants of enhancing services trade.

As mentioned before, the second channel through which the quality of maritime services is transmitted to influence trade facilitation is the improvement in the quality of accompanying logistics services because of improving the efficiency of institution border factors. One of the main factors that can help to expand trade accessibility is to focus on investing in maritime and port infrastructure, which help improving logistics performance and to create a better business environment ${ }^{11}$. This enhances the opportunities of the country to facilitate trade (Lakshmanan, 2011; Munim and Schramm, 2018; Wilmsmeier and Hoffmann, 2008).

Lakshmanan (2011) argued that there are many benefits from investing in transportation infrastructure beyond that of the traditional effect on transport supply and demand. These include benefiting from lower logistics costs, technology diffusion, facilities consolidations, opening up markets, achieving gains from trade and enhancing the efficiency of factor markets.

\footnotetext{
${ }^{11}$ Here, it is assumed that investments in maritime port infrastructure are exogenous in trade models.
} 


\title{
Scientific Journal for Financial and Commercial Studies and Researches
}

\author{
Dr. Khaled El-Sakty and Dr. Ahmed Ezzat
}

Wilmsmeier and Hoffmann (2008) analyzed port infrastructure and liner shipping connectivity as a determinant of Caribbean international maritime freight rates. They measured international freight rates for 189 Caribbean lanes for standard 20-foot standard containers in July 2006. It was found that a shred of strong evidence for the close relationship between port infrastructure, liner shipping services and liner shipping freight rates. Estimation showed that a USD 287 reduction in freight rate results from one standard deviation improvement in maritime connectivity. Moreover, one standard deviation improves in port infrastructure results in a reduction of USD 225 in freight rate.

UNCTAD (2013) confirmed the same relationship between maritime connectivity and trade while studying the effects of maritime connectivity on the bilateral trade of containerized goods. Data are collected for 178 countries over the period 2006-2012. Using a standard gravity model, estimation suggests that the lack of direct connection between partners results in a decline in the export value of between 42 and 55 percent. Hence, the study confirmed the importance of having maritime connectivity to be the core of any strategy that targets improving export competitiveness.

Munim and Schramm (2018) tested how can the quality of port infrastructure affects maritime trade directly and indirectly through affecting logistics performance. Data are collected for 91 countries with seaports for the years 2010, 2012 and 2014 using a structural equation model. Findings supported the positive effect of port infrastructure on maritime trade through logistics performance. Accordingly, the results recommended developing countries to find ways to continuously improve the quality of maritime port infrastructure as it contributes to improving logistics performance, leading to an increase in maritime trade. 


\title{
Scientific Journal for Financial and Commercial Studies and Researches
}

\author{
Dr. Khaled El-Sakty and Dr. Ahmed Ezzat
}

Lun et al. (2016) investigated the relationship between trade costs and trade facilitation on both macro and micro levels. Data used are collected from the World Bank database of logistics performance index ((LPI) as a proxy for trade facilitation in 2012. As known, LPI consists of six items including; the efficiency of customs and border management clearance 'Customs', the quality of trade and transport infrastructure 'Infrastructure', the ease of arranging competitively priced shipments 'Ease of arranging shipments', the competence and quality of logistics services - trucking, forwarding, and customs brokerage 'Quality of logistics services', the ability to track and trace consignments 'Tracking and tracing', and the frequency with which shipments reach consignees within scheduled or expected delivery times 'Timeliness'. Using a structural equation model, the findings confirmed the significant negative relationship between trade costs and trade facilitation.

\subsection{Digital Transformation as a Source of Competitive Advantage in Maritime Service}

Little theoretical and experimental attention has been devoted to the impact of digitization on gaining a competitive advantage in maritime service. The reason for this is that almost 97 percent of world container ports are not automated (UNCTAD, 2018). The literature review revealed that several channels through which digitalization can affect the competitiveness of maritime transport. These channels include the impact of digitalization on enhancing productivity, efficiency, safety and sustainability of maritime services (Munim and Schramm, 2018; UNCTAD, 2013; UNCTAD, 2018). UNCTAD (2019) stated that shipping connectivity, which is closely related to digitization, is considered one of the main proxies in measuring efficiency, access to markets, trade facilitation and sustainability measures. 


\section{Scientific Journal for Financial and Commercial Studies and Researches}

Dr. Khaled El-Sakty and Dr. Ahmed Ezzat

An industry survey conducted on global terminal operators in the maritime sector focused only on productivity and efficiency channels of the impact of digitization on the competitiveness of maritime transport. The survey revealed that about 75 percent of terminal operators consider automation of maritime operations as critical to secure competitiveness. Also, 65 percent of respondents in the same survey see automation as an operational safety lever. Over 60 percent of respondents asserted that automating maritime operations helps improve operational processes and consistency between parties involved in the global maritime transport industry. About 81 percent of respondents estimate that automating maritime operations reduces overall operational $\operatorname{costs}^{12}$. About 59 percent of respondents believed that automation increases productivity ${ }^{13}$ (UNCTAD, 2018).

Heilig et al. (2017) added the environmental dimension to productivity and efficiency channels in studying the relationship between DT and competitiveness in the maritime sector. They divided technological transformation in maritime services into three main generations and there are different ways to achieve added value in each generation as a basis for reaping a competitive advantage. In the first generation "the transformation to paperless procedures", the main sources of gaining an added value includes the use of information to improve planning and managing operations in

\footnotetext{
${ }^{12}$ Out of this 81 percent: 19 percent stated that the estimated reduction in operating costs because of automating operations could exceed 50 percent, 29 percent stated that the estimated reduction in operating costs ranges between 26-50 percent and 33 percent of them stated that the estimated reduction in operating costs ranges between 16-25 percent.

${ }^{13}$ Out of this 59 percent: 30 percent believed that the estimated increase in productivity because of automation ranges between $26-50$ percent and 29 percent stated that the estimated increase ranges between 16-25 percent.
} 


\section{Scientific Journal for Financial and Commercial Studies and Researches}

\section{Dr. Khaled El-Sakty and Dr. Ahmed Ezzat}

terminals, minimize errors and time of using paper documents and enhancing the accessibility and exchange of information to improve procedures and transactions at ports. The second-generation "the transformation to automated procedures", can help to gain an added value through automating terminal facilities that leads to improving the efficiency of using resources, facilitating procedures and minimizing information asymmetries, improving information exchange along with the global logistics networks, supporting efforts for alliances. The improvements in sharing and integrating information will help in accelerating efforts towards having common standards for information exchange between strategic partners. The third-generation "the transformation to smart procedures" can add value through improving the efficiency of operations of ports and terminals relying on data-driven decision making, improving the awareness of environmental impacts and merging all parties involved in decision making.

Tijan et al. (2019) focused more on the channels of efficiency and sustainability when they studied the impacts of information integration and having a maritime national single window on competitiveness and sustainability in seaports and maritime industry. They stated that using paper procedures in addition to multiple entries to data leads to higher costs and increased errors. Hence, the use of a single window, relying on digitalization, gives the ability to enter necessary data once and reuse it when needed. Applying on European Maritime Single Window and National Single Windows (NSW) and maritime NSW in Azerbaijan, Benin, Korea, Malaysia, Netherlands, Thailand and Senegal, the digitization and adopting a singlewindow model make maritime business more competitive. Based on the applications, the main economic benefits have cost reduction as a result of 


\section{Scientific Journal for Financial and Commercial Studies and Researches}

\section{Dr. Khaled El-Sakty and Dr. Ahmed Ezzat}

eliminating paper documents ${ }^{14}$ and processing, delivery and border crossing time savings because of eliminating paper collecting time and accelerating custom procedures ${ }^{15}$. Consequently, fees can also be reduced as an important component of seaports' competitive advantage strategies. Socially, the benefits include the efficient use of human resources, improving the productivity of employees, reducing the workload and improving communication and information exchange. On the environmental aspect of maritime sustainability, the main benefits include the efficient use of natural resources and reducing emissions as a result of eliminating unnecessary movements of cargo and eliminating paper documents.

UNCTAD studies stated that the link between automation of operations and the previous dimensions of competitiveness depends on the ability to overcome several challenges. These challenges include integration of different innovations in one system, absorbing the potential disruptions in the labor market because of the expected shrink in the number of jobs and changes in skills required, making regulatory changes to cope with automation, unifying standards and strengthen collaboration mechanisms among all stakeholders, reviewing international maritime laws and regulations to reassess the roles of a human crew working onboard and ashore (UNCTAD, 2013; UNCTAD, 2018; UNCTAD, 2019).

\footnotetext{
${ }^{14}$ The estimated cost reduction because of adopting a national maritime single window in Thailand is USD 9.5 million annually.

${ }^{15}$ Documents collecting time are reduced because of NSW in Senegal from 4 days to one day. There is a reduction in cargo turnover time because of having NSW in Malaysia from 4 days to 2 days and in Benin from 39 days to 6 days. There was a reduction in border-crossing time because of having an NSW in Azerbaijan from 180 minutes to 20 minutes.
} 
Scientific Journal for Financial and Commercial Studies and Researches

Dr. Khaled El-Sakty and Dr. Ahmed Ezzat

UNCTAD (2018) illustrated that the maritime sector has to overcome these challenges to effectively reap the benefits of digitalization. This requires the concerted efforts of all stakeholders, including policymakers, maritime authorities, investors, ports, terminal operators and technology makers. This is to adopt production patterns compatible with digitization, study the requirements of new labor skills and adjust policies to deal with potential disruptions in the labor market and coordinate to provide common standards for work and performance evaluation.

\subsection{Research Gap and Hypotheses}

From a review of the literature, it became clear that despite the accelerated trend of digitalization in maritime sector and that many studies investigated and confirmed the effects of quality of maritime services on competitiveness and trade facilitation. Few studies analyzed the effects of DT on the competitiveness of maritime services. A smaller number of studies examined these effects based on the quality of maritime services. None of these studies used the quality of service dimensions in the maritime service domain (ROPMIS) empirically to study the effects of DT on the competitiveness of marine services. Therefore, this paper has addressed the problem of investigating the strength of the relationship between the DT and service quality dimensions as a tool to improve the maritime competitiveness of the Suez Canal. 
Scientific Journal for Financial and Commercial Studies and Researches

Dr. Khaled El-Sakty and Dr. Ahmed Ezzat

Based on the research problem, the following objectives are addressed:

1. Examining the relationship between service quality dimensions and DT.

2. Investigating the impact of DT on improving port competitiveness.

3. Studying the role of DT in improving SC competitiveness.

To achieve the objectives of the research, the main research null hypothesis has been formulated as:

$\mathrm{H}_{0}$ : DT does not have a significant effect on maritime competitiveness based on service quality dimensions in Suez Canal maritime services (SCMS).

Relying on the six dimensions of service quality (ROPMIS) provided by Thai (2008), the sub-hypotheses driven from the main null hypothesis have been formulated as follows:

$\mathrm{H}_{01}$ : DT does not have a significant effect on Resources in SCMS

$\mathrm{H}_{02}$ : DT does not have a significant effect on Outcomes in SCMS

$\mathrm{H}_{03}$ : DT does not have a significant effect on Process in SCMS

$\mathrm{H}_{04}$ : DT does not have a significant effect on Management in SCMS

$\mathrm{H}_{05}$ : DT does not have a significant effect on Image and Social Responsibility in SCMS 
Scientific Journal for Financial and Commercial Studies and Researches

Dr. Khaled El-Sakty and Dr. Ahmed Ezzat

\section{Research Methodology and Case Study}

This section is divided into two subsections. The first is to construct the survey. The second is to describe the case study in addition to showing the reason for selecting it.

\subsection{Constructing the Survey}

An exploratory approach is applied using a qualitative research process by conducting a survey sample on SCMS as a case study. Descriptive analysis, regression model and Analysis of Variance test (ANOVA) have been applied to indicate the effect of DT on maritime competitiveness based on service quality in SCMS.

To test the hypotheses, a survey was designed based on a five-point LIKERT scale for evaluating the questionnaire, which consists of three sections including 40 statements of multiple-choice questions are comprised of five potential choices ranking from the rating of "strongly agree" to the rating of "strongly disagree". Section one includes demographic factors as basic information of the participant as gender, age, experience, educational level. Section two measures the implementation of DT in SCMS as a total of 11 questions covering the three main generations in the development of DT in the maritime services domain: paperless procedures, automated procedures and smart procedures. Section three uses 29 questions to measure the effects of DT on maritime competitiveness based on service quality in SCMS using five indicators: resource, outcome, process, management and image and social responsibility (table1\&2). Questions are selected according to the contribution of the literature review, the experience of the researchers in the maritime services domain and the nature of the case study (SCMS). 
Scientific Journal for Financial and Commercial Studies and Researches

Dr. Khaled El-Sakty and Dr. Ahmed Ezzat

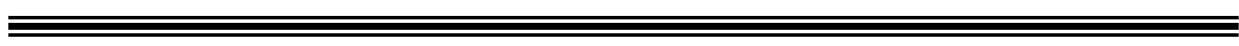

Table 1

Dimensions of Measuring Digital transformation used in the survey

\begin{tabular}{|c|c|c|}
\hline Dimensions & Factors & $\begin{array}{c}\text { No. of } \\
\text { questions }\end{array}$ \\
\hline \multirow[t]{3}{*}{$\begin{array}{c}\text { Paperless } \\
\text { Procedures }\end{array}$} & $\begin{array}{l}\text { - Basic IT infrastructure and software } \\
\text { applications availability. }\end{array}$ & 1 \\
\hline & - Common EDI standers availability. & 1 \\
\hline & - Port Community system availability. & 1 \\
\hline \multirow[t]{3}{*}{$\begin{array}{l}\text { Automated } \\
\text { procedures }\end{array}$} & $\begin{array}{l}\text { - A (semi-) automated control of the } \\
\text { transiting system. }\end{array}$ & 1 \\
\hline & $\begin{array}{l}\text { - Initiatives for improving accessibility } \\
\text { with ships. }\end{array}$ & 1 \\
\hline & $\begin{array}{l}\text { - Single windows providing a single } \\
\text { entry point. }\end{array}$ & 1 \\
\hline \multirow{5}{*}{$\begin{array}{c}\text { Smart } \\
\text { procedures }\end{array}$} & - Using cloud computing concept. & 1 \\
\hline & - Using smart devices. & 1 \\
\hline & - Using internet of things. & 1 \\
\hline & - Using sophisticated data analytics. & 1 \\
\hline & $\begin{array}{l}\text { - Using smart sensors and global } \\
\text { networks. }\end{array}$ & 1 \\
\hline Total & & 11 \\
\hline
\end{tabular}

Source: Prepared by the researchers. 
Scientific Journal for Financial and Commercial Studies and Researches

Dr. Khaled El-Sakty and Dr. Ahmed Ezzat

Table 2

Dimensions of Measuring Competitiveness in SCMS Relying on Services Quality used in the survey

\begin{tabular}{|c|c|c|}
\hline Dimensions & Factors & $\begin{array}{c}\text { No. of } \\
\text { questions }\end{array}$ \\
\hline \multirow[t]{5}{*}{ Resources } & - Equipment and facilities availability. & 1 \\
\hline & - Equipment and facilities condition. & 1 \\
\hline & - Financial stability. & 1 \\
\hline & - Shipment tracking capability. & 1 \\
\hline & - Physical infrastructures. & 1 \\
\hline \multirow[t]{7}{*}{ Outcomes } & - The speed of service performance. & 1 \\
\hline & - Reliability of service performance. & 1 \\
\hline & - Consistently providing service. & 1 \\
\hline & - Transiting safety and security. & 1 \\
\hline & $\begin{array}{l}\text { - Reliability of documentation (error-free } \\
\text { processes). }\end{array}$ & 1 \\
\hline & - Competitive price of service. & 1 \\
\hline & $\begin{array}{l}\text { Availability of services anytime and } \\
\text { anywhere we want. }\end{array}$ & 1 \\
\hline \multirow[t]{2}{*}{ Processes } & $\begin{array}{l}\text { - Staff's attitude and behavior in meeting } \\
\text { customers' requirements. }\end{array}$ & 1 \\
\hline & $\begin{array}{l}\text { Quick response to customers' inquiries } \\
\text { and requests. }\end{array}$ & 1 \\
\hline
\end{tabular}


Scientific Journal for Financial and Commercial Studies and Researches

Dr. Khaled El-Sakty and Dr. Ahmed Ezzat

\begin{tabular}{|c|c|c|}
\hline & $\begin{array}{l}\text { - Knowledge of customers' needs and } \\
\text { requirements. }\end{array}$ & 1 \\
\hline & $\begin{array}{l}\text { Application of IT and EDI in customer } \\
\text { service. }\end{array}$ & 1 \\
\hline \multirow[t]{6}{*}{ Management } & - Application of IT and EDI in operations & 1 \\
\hline & - Efficiency in operations and management. & 1 \\
\hline & $\begin{array}{l}\text { Knowledge and skills of management and } \\
\text { operators. }\end{array}$ & 1 \\
\hline & $\begin{array}{l}\text { - Understanding customers' needs and } \\
\text { requirements. }\end{array}$ & 1 \\
\hline & - Feedback from customers. & 1 \\
\hline & $\begin{array}{l}\text { Continuous improvement of customer- } \\
\text { oriented operation processes. }\end{array}$ & 1 \\
\hline \multirow[t]{2}{*}{ Image } & $\begin{array}{l}\text { Relationship with other authorities and } \\
\text { maritime service providers. }\end{array}$ & 1 \\
\hline & - Reputation for reliability in the market. & 1 \\
\hline \multirow[t]{3}{*}{$\begin{array}{l}\text { Social } \\
\text { responsibility }\end{array}$} & $\begin{array}{l}\text { - Socially responsible behavior and } \\
\text { concerns for human safety. }\end{array}$ & 2 \\
\hline & $\begin{array}{l}\text { Social responsibility to employees and } \\
\text { other stakeholders }\end{array}$ & 1 \\
\hline & - Environmentally safe operations. & 2 \\
\hline Total & & 29 \\
\hline
\end{tabular}

Source: Prepared by the researchers. 
Scientific Journal for Financial and Commercial Studies and Researches

Dr. Khaled El-Sakty and Dr. Ahmed Ezzat

\subsection{Describing the Case Study}

SC is an artificial sea-level waterway in Egypt. It links between the Mediterranean Sea at Port Said and the red sea at Suez. SC is the longest canal without locks worldwide. SC is considered an important international navigation canal as it is considered to be the shortest link between the east and the west due to its unique geographic location. The unique geographical position gives it a competitive advantage as it saves distance, time, fuel consumption and ship operating costs of international trade. This makes SC of special importance to the world and Egypt as well.

According to the data of the SC Authority, the SC share is $9 \%$ of the world seaborne trade, $24 \%$ of the world container trade ${ }^{16}$. As well, the SC accommodates approximately a billion tons annually (food - medicine - fuel - humane necessities). According to SC authority statistics, 18,880 ships made a full transit through the SCT in 2019 with around 104 different ship flags, 1.21 billion tons of payload and 47.9 vessels on average daily. Container ships and tankers dominate the vessels transiting the canal according to ship type, with a share of $28 \%$ and $27 \%$, respectively, followed by bulk ships with a share of 22\% (Suez Canal Authority, 2019).

\footnotetext{
${ }^{16}$ The term potential trade of SC refers to the trade that the SC lies within one of its potential routes. 
Scientific Journal for Financial and Commercial Studies and Researches

Dr. Khaled El-Sakty and Dr. Ahmed Ezzat

Alternative routes to SC can be classified into three main routes including sea routes, railways, roads and oil and gas pipelines. These main routes are the Panama Canal after its expansion in 2015, Cape Route and Northern Sea Route (El-Sakty, 2014).

Enhancing the competitiveness of maritime services provided is explicitly included in both the vision and mission of the SC authority while offering its services. The vision includes:

- Keeping the SC the first choice for shipping companies, liners, ship owners and ship operators.

- Raising the SC's share of the world seaborne trade that uses the Canal.

- Rendering a distinguished and uninterrupted service to vessels that transit the SC.

The mission of the SC authority focuses on:

- Managing and operating SC to increase its capabilities and competitive position.

- Realizing customers' expectations through continuous improvement of the entire operating system.

- Upgrading the performance of the SC to cope with the requirements and challenges in addition to exploiting available opportunities in the international shipping market.

In line with the vision and mission of the SC Authority, the authority has tended to support competitiveness by adopting several tools, including the use of applications for digital technologies in its maritime services. Depending on the dimensions of DT introduced in the literature review, SC authority recently initiated a DT on its services, but it is still at the very beginning of the DT process. Hence, choosing SCMS as a case study can enhance directing the initiatives adopted by SC Authority towards the most important activities that can significantly support the competitiveness of maritime services provided. 
Scientific Journal for Financial and Commercial Studies and Researches

Dr. Khaled El-Sakty and Dr. Ahmed Ezzat

\section{Data Analysis and Empirical Results}

In this section, a statistical analysis of the data obtained from the questionnaire is going to be investigated to test the research hypothesis. Statistical analysis includes verifying the validity and reliability of the data and drawing conclusions.

The population of the study is considered to be broad. The survey is designed with a target population of around 471 navigation agents who are served by SC authority ${ }^{17}$. In calculating the sample size, the "Richard Geiger equation" is used. The results of the equation indicated the optimal size of the sample to be 114 clients with a $95 \%$ confidence level. However, to accommodate for potential human error and aiming for more accurate results, a sample size of 170 clients was used. Out of the 170 questionnaires distributed, 150 usable responses were received with a response rate of $88.24 \%$.

Quantitative data collected using the questionnaire were analyzed using descriptive statistics including averages and frequencies as measures of central tendency and standard deviation as a measure of dispersion. Additionally, both the regression model and ANOVA tests were used to estimate the effects of DT on maritime competitiveness based on service quality.

The internal consistency of each statement of the questionnaire was measured by calculating Pearson correlation coefficients between each statement included in each section of the questionnaire and the total score for the same section. All the statements of the three sections of DT development and the five sections of the effects of DT on maritime competitiveness based on service quality in SCMS are valid for what they aimed to measure (Table3).

\footnotetext{
${ }^{17}$ The researchers targeted three individuals per office of 157 Navigation agents listed on the SC authority official website. 


\title{
Scientific Journal for Financial and Commercial Studies and Researches
}

\author{
Dr. Khaled El-Sakty and Dr. Ahmed Ezzat
}

\section{Table 3}

Testing the validity of statements of the dimensions of digital transformation and service quality in SCMS using correlation coefficients

Testing the validity of statements of the dimensions of digital transformation

A. Correlation coefficients between each statement of the first factor "paperless procedures" and the total score of the factor

\begin{tabular}{|l|l|c|}
\hline No & \multicolumn{1}{|c|}{ Statements } & $\begin{array}{c}\text { Correlation } \\
\text { Coefficient }\end{array}$ \\
\hline 1 & $\begin{array}{l}\text { SC authority "SCA" has basic information technology "IT" } \\
\text { infrastructure and software applications to support its activities. }\end{array}$ & 0.916 \\
\hline 2 & $\begin{array}{l}\text { SCA has common electronic data interchange "EDI" stander to } \\
\text { enhance electronic documents exchange with internal and external } \\
\text { actors. }\end{array}$ & 0.956 \\
\hline 3 & $\begin{array}{l}\text { SCA has port community system to facilitate paperless document } \\
\text { exchange in its community. }\end{array}$ & 0.892 \\
\hline $\begin{array}{l}\text { B. Correlation coefficients between each statement of the second factor "automated } \\
\text { procedures" and the total score of the factor }\end{array}$ & 0.908 \\
\hline 1 & $\begin{array}{l}\text { The integration and data availability in SCA community allows a } \\
\text { (semi-) automated control of SC transiting system. }\end{array}$ & 0.925 \\
\hline 2 & SCA has formed initiatives for improving accessibility with ships. \\
\hline 3 & $\begin{array}{l}\text { SCA has developed single windows providing a single entry point } \\
\text { to fulfill all regulatory requirements in SC transiting procedures. }\end{array}$ & 0.850 \\
\hline C. Correlation coefficients between each statement of the third factor "smart \\
procedures" and the total score of the factor.
\end{tabular}




\section{Scientific Journal for Financial and Commercial Studies and Researches}

\section{Dr. Khaled El-Sakty and Dr. Ahmed Ezzat}

\begin{tabular}{|l|l|c|}
\hline \hline 4 & $\begin{array}{l}\text { SCA capture a large volume of information from a variety of } \\
\text { sources and process it using sophisticated analytics to significantly } \\
\text { improve the decision making. }\end{array}$ & 0.857 \\
\hline 5 & $\begin{array}{l}\text { SCA uses smart sensors and global networks for data transfer from } \\
\text { ships to SCA. }\end{array}$ & 0.823 \\
\hline \multicolumn{3}{|c|}{ Testing the validity of statements of the dimensions of service quality } \\
\hline $\begin{array}{l}\text { A. Correlation coefficients between each statement of the first factor "Resources" and } \\
\text { the total score of the factor }\end{array}$ & 0.761 \\
\hline 1 & $\begin{array}{l}\text { SCA has available equipment and facilities to meet our } \\
\text { requirements. }\end{array}$ & 0.716 \\
\hline 2 & $\begin{array}{l}\text { The equipment and facilities of SCA are modern and always } \\
\text { function properly. }\end{array}$ & 0.607 \\
\hline 3 & SCA has strong and stable financial stability. & 0.779 \\
\hline 4 & SCA has an excellent transiting tracing capability. & 0.689 \\
\hline 5 & $\begin{array}{l}\text { SCA has excellent physical infrastructure such as berths, yards, } \\
\text { warehouses and hinterland connection networks. }\end{array}$ & 0.889 \\
\hline B. Correlation coefficients between each statement of the second factor "Outcomes" \\
and the total score of the factor. \\
\hline 1 & SCA always provide fast service. & 0.744 \\
\hline 2 & SCA always provide service in a reliable manner. & 0.856 \\
\hline 3 & SCA provide service in a consistent manner. & 0.769 \\
\hline 4 & SCA always ensure safety and security to our ships. \\
\hline 5 & SCA always produce an error-free invoice and related documents. \\
\hline 6 & SCA offers a competitive price of service. \\
\hline 7 & $\begin{array}{l}\text { SCA always meet our service requirements anytime and anywhere } \\
\text { we want. }\end{array}$ & $\begin{array}{l}\text { The staff in SCA always responds quickly to our enquiries and } \\
\text { request. }\end{array}$ \\
\hline C. Correlation coefficients between each statement of the third factor "Process" and \\
the total score of the factor \\
\hline 1 & $\begin{array}{l}\text { The staff in SCA always demonstrates professional attitude and } \\
\text { behavior in meeting our requirements. }\end{array}$ & 0.868 \\
\hline 2 & SCA \\
\hline
\end{tabular}




\title{
Scientific Journal for Financial and Commercial Studies and Researches
}

\author{
Dr. Khaled El-Sakty and Dr. Ahmed Ezzat
}

\begin{tabular}{|l|l|c|}
\hline \hline 3 & $\begin{array}{l}\text { The staff in SCA always demonstrates good knowledge of our needs } \\
\text { and requirements. }\end{array}$ & 0.930 \\
\hline 4 & $\begin{array}{l}\text { The level of information and communication technology "ICT" } \\
\text { applications in customer service at SCA is comprehensive. }\end{array}$ & 0.893 \\
\hline $\begin{array}{l}\text { D. Correlation coefficients between each statement of the fourth factor "Management" } \\
\text { and the total score of the factor }\end{array}$ & $\begin{array}{l}\text { The level of ICT applications in operations and management at SCA } \\
\text { is comprehensive. }\end{array}$ & 0.847 \\
\hline 2 & $\begin{array}{l}\text { SCA demonstrates a high level of efficiency in operations and } \\
\text { management. }\end{array}$ & 0.845 \\
\hline 3 & $\begin{array}{l}\text { The management in SCA always demonstrates good knowledge and } \\
\text { competence, including incident-handling capability. }\end{array}$ & 0.835 \\
\hline 4 & $\begin{array}{l}\text { The management in SCA always demonstrates a good } \\
\text { understanding of our needs and requirements. }\end{array}$ & 0.891 \\
\hline 5 & $\begin{array}{l}\text { SCA always collect our feedback about its services and reflect on } \\
\text { its improvement. }\end{array}$ & 0.810 \\
\hline 6 & $\begin{array}{l}\text { SCA continuously improve its customer-oriented operation and } \\
\text { management processes. }\end{array}$ & 0.882 \\
\hline E. Correlation coefficients between each statement of the eighth factor "Image \& \\
Social responsibility" and the total score of the factor
\end{tabular}

Source: Prepared by the researchers depending on statistical results of the questionnaire. 
Scientific Journal for Financial and Commercial Studies and Researches

Dr. Khaled El-Sakty and Dr. Ahmed Ezzat

Additionally, structural validity is used to show the relevance of each section of the study to the total score of the statements of the questionnaire. The correlation coefficients between the total value of each factor and the overall total value of the factors of the questionnaire confirmed the validity of the statements of the questionnaire to measure the objective for which they were put (Table 4).

Table 4

Testing the structural validity of total value of each factor and the overall value of factors of the questionnaire using correlation coefficients

\begin{tabular}{|c|c|c|}
\hline \multicolumn{3}{|c|}{ Testing the validity of the dimensions of digital transformation } \\
\hline Factor & Content of the factor & $\begin{array}{c}\text { Correlation } \\
\text { Coefficient }\end{array}$ \\
\hline First & paperless procedures & 0.883 \\
\hline Second & automated procedures & 0.873 \\
\hline Third & smart procedures & 0.608 \\
\hline
\end{tabular}

Testing the validity of statements of the dimensions of service quality

\begin{tabular}{|c|c|c|}
\hline First & Resources & 0.803 \\
\hline Second & Outcomes & 0.851 \\
\hline Third & Process & 0.841 \\
\hline Fourth & Management & 0.885 \\
\hline Fifth & Image \& Social responsibility & 0.773 \\
\hline
\end{tabular}

Source: Prepared by the researchers depending on statistical results of the questionnaire. 
Scientific Journal for Financial and Commercial Studies and Researches

Dr. Khaled El-Sakty and Dr. Ahmed Ezzat

Cronbach's alpha coefficients were used as a measure of internal consistency. The coefficients indicate a high degree of persistence of the study sample and a high level of internal consistency for the scale with this specific sample (Table 5).

Table 5

CRONBACH'S alpha coefficients

\begin{tabular}{|c|c|c|}
\hline Variables & $\begin{array}{c}\text { Number of } \\
\text { statements }\end{array}$ & $\begin{array}{c}\text { CRONBACH'S } \\
\text { ALPHA coefficients }\end{array}$ \\
\hline Digital transformation & 11 & 0.903 \\
\hline Service quality & 29 & 0.964 \\
\hline Total & 40 & 0.968 \\
\hline
\end{tabular}

Source: Prepared by the researchers depending on statistical results of the questionnaire.

To test the research hypothesis, the five sub-hypotheses were examined concerning whether there is no positive impact of DT on resources, outcomes, process, management and image and social responsibility in SCMS. The bivariate Correlation coefficient, coefficient of determination, simple linear regression analysis and ANOVA test are used to investigate the relationships needed to test the research hypothesis.

Results of testing the five sub-hypothesis rejected the null hypothesis and confirmed the positive impact of DT on the five dimensions of service quality to gain maritime competitiveness in SCMS (Table 6). 
Scientific Journal for Financial and Commercial Studies and Researches

Dr. Khaled El-Sakty and Dr. Ahmed Ezzat

Table 6

Testing hypothesis statistical results

\begin{tabular}{|c|c|c|c|c|}
\hline \multicolumn{5}{|c|}{$\mathrm{H}_{01}$ : Digital transformation has a significant impact on Resources } \\
\hline & $\mathrm{R}^{2}$ & Adj. $R^{2}$ & DT Unst. Coeff. $^{+}$ & ANOVA F stat. \\
\hline & 0.604 & 0.601 & $0.564 * * *$ & $225.3 * * *$ \\
\hline \multicolumn{5}{|c|}{$\mathrm{H}_{02}$ : There is no positive impact of Digital transformation on Outcomes } \\
\hline & $\mathrm{R}^{2}$ & Adj. $\mathrm{R}^{2}$ & DT Unst. Coeff. $^{+}$ & ANOVA F stat. \\
\hline & 0.560 & 0.557 & $0.604 * * *$ & $188.6^{* * *}$ \\
\hline \multicolumn{5}{|c|}{$\mathrm{H}_{03}$ : There is no positive impact of Digital transformation on Process. } \\
\hline & $\mathrm{R}^{2}$ & Adj. $R^{2}$ & DT Unst. Coeff. ${ }^{+}$ & ANOVA F stat. \\
\hline & 0.562 & 0.559 & $0.751 * * *$ & $190.1 * * *$ \\
\hline \multicolumn{5}{|c|}{$\mathrm{H}_{04}$ : There is no positive impact of Digital transformation on Management } \\
\hline & $\mathrm{R}^{2}$ & Adj. $R^{2}$ & DT Unst. Coeff. $^{+}$ & ANOVA F stat. \\
\hline & 0.636 & 0.634 & $0.724 * * *$ & $258.7 * * *$ \\
\hline \multicolumn{5}{|c|}{$\begin{array}{l}\mathrm{H}_{05} \text { : There is no positive impact of Digital transformation on Image \& Social } \\
\text { Responsibility }\end{array}$} \\
\hline & $\mathrm{R}^{2}$ & Adj. $\mathrm{R}^{2}$ & DT Unst. Coeff. $^{+}$ & ANOVA F stat. \\
\hline & 0.452 & 0.449 & $0.533 * * *$ & $122.3 * * *$ \\
\hline
\end{tabular}

Source: Prepared by the researchers.

${ }^{+}$DT Unst. Coeff. Refers to digital transformation unstandardized

Coefficient in the model.

${ }^{* * *}$ Statistically significant at 1 percent level. 


\section{Scientific Journal for Financial and Commercial Studies and Researches}

Dr. Khaled El-Sakty and Dr. Ahmed Ezzat

The results of regressing DT on the five dimensions of service quality indicated that a one-unit increase in DT as an independent variable leads to an increase in process, management, outcomes, resources and image and social responsibility by $0.751,0.724,0.604,0.564$ and 0.533 respectively. Hence, the strongest channel that can link the DT to affect maritime competitiveness of SCMS based on service quality is process followed by management and outcomes then resources followed by image and social responsibility. The positive sign of these coefficients is consistent with theoretical explanation as mentioned before in the study of Thai (2008). These coefficients are highly significant at 1 per cent level. It is thus empirically proven that services quality dimensions can be enhanced through adopting DT. Hence, results reject both of the main null hypothesis and sub- hypotheses in case of SCMS. Accordingly, DT can be used to enhance maritime competitiveness based on service quality dimensions in SCMS.

The coefficients of determination $\left(\mathrm{R}^{2}\right)$ imply that the variations in the dependent variables (resources, outcomes, processes, management and image and social responsibility) are interpreted by variations in the independent variable (DT) at the extent of $60.4 \%, 56 \%, 56.2 \%, 63.6 \%$ and $45.2 \%$ respectively. This means that the highest interpretive ability to improve the dimensions of service quality as a result of the digital transformation was in management then resources followed by processes and outcomes and the least were in image and social responsibility. 


\title{
Scientific Journal for Financial and Commercial Studies and Researches
}

\author{
Dr. Khaled El-Sakty and Dr. Ahmed Ezzat
}

The possibility of having significant changes in these results depending on demographic factors differences in the sample used was tested. The results confirmed that the disparity of gender, age group, level of education and years of experience do not affect results significantly.

\section{Conclusion and Policy Implications}

In this paper, the impact of applying digital technologies in maritime services on gaining a competitive advantage based on service quality in SCMS is investigated. Following the literature, six dimensions of measuring service quality in the maritime services domain are used. These six dimensions are resources, outcomes, processes, management, image and social responsibility. A survey is used covering navigation agents who are served by SC authority for two main purposes. The first purpose is to study how DT can affect the quality of service in the maritime services domain. The second purpose is to determine the channels through which DT is transmitted to influence competitiveness in SCMS. In estimating results, statistical analysis, regression model and ANOVA test are used to indicate the effect of DT on maritime competitiveness based on service quality in SCMS.

The results confirmed the positive impact of DT in affecting maritime competitiveness based on service quality in SCMS. The six dimensions of service quality are found to be significantly positively affected by DT. The strongest channel that can link the DT to affect the maritime competitiveness of SCMS based on service quality is processes followed by management and outcomes, resources and image and social responsibility. 


\section{Scientific Journal for Financial and Commercial Studies and Researches}

\section{Dr. Khaled El-Sakty and Dr. Ahmed Ezzat}

The findings of the questionnaire shows the need for directing SC authority to more focus on investing more in physical infrastructure and human capital targeting the adoption of automated and smart procedures that can lead to:

1. Understanding customers' needs and requirements, improving customeroriented operation processes and having feedback from customers.

2. Improving the awareness of management and operators about the need for DT, then train them to improve their skills to maximize the gains from DT.

3. Enhancing the quick response to customers' inquiries and requests in addition to improving the quality of customer service.

4. Supporting the speed, reliability, safety and security of documentation and service performance.

5. Offering services at any time and in any place the customer wants.

6. Facilitating the communications and operations with other authorities and maritime service providers.

7. Promoting the maritime services to gain more reliability in the market.

8. Improving shipment tracking capability.

According to the results and the priorities of influencing the quality of maritime services through DT, it is possible to stimulate the positive impact of DT on the quality of marine services and maritime competitiveness in SC through:

1. Adopting the transformation gradually. Starting from the activities that imply only very little changes like paperless procedures using emails. As a second stage, technical integration is required including electronic data interchange. As a third stage, internal structures and processes redesign can 
Scientific Journal for Financial and Commercial Studies and Researches

Dr. Khaled El-Sakty and Dr. Ahmed Ezzat

be started as a step towards starting automated procedures. The next step can be redesigning business networks with external stakeholders.

2. Focusing investment on physical infrastructure to use IT and EDI in operations and customer service.

3. Investing more in human capital to enhance the abilities of staff to use IT and EDI in operations, improve the awareness of the importance of using IT and EDI in operations and customer service.

4. Enhancing the facilitation of communications and operations with other authorities and maritime service providers.

5. Adopting partnerships with external shipping partners to provide technology for DT and benefit from the digitization of operations, focusing on digitizing document management, communication networks, and tracking systems. 


\section{Scientific Journal for Financial and Commercial Studies and Researches}

Dr. Khaled El-Sakty and Dr. Ahmed Ezzat

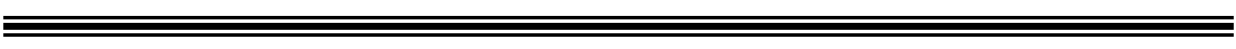

\section{REFERENCES}

Azapmo, J. B. (2017) Regional trade agreements and cross-border trade costs: The case of Pacific island countries. ARTNeT Working Paper Series, No. 165, Asia-Pacific Research and Training Network on Trade (ARTNeT), Bangkok

Babica V., Sceulovs D. and Rustenova E. (2020) Digitalization in Maritime Industry: Prospects and Pitfalls. In: Ginters E., Ruiz Estrada M., Piera Eroles M. (eds) ICTE in Transportation and Logistics 2019 pp 20-27. Lecture Notes in Intelligent Transportation and Infrastructure. Springer, Cham. https://doi.org/10.1007/978-3-030-39688-6_4

Chahal H. and N. Kumari (2012). Service Quality and Performance in the Public Health-Care Sector, Health Marketing Quarterly, 29:3, 181-205. https://doi.org/10.1080/07359683.2012.704837

El-Sakty K. (2014). Suez Canal Logistics Hub: Competition and Challenges. Journal of Supply Chain Management: Research and Practice, vol. 8 no 1. https://jscm.au.edu/index.php/jscm/article/view/98/64

Epo B. and R. Nguenkwe (2020). Information and Communication Technology and Intra-Regional Trade in the Economic Community of West African States: Ambivalent or Complementary? Economics Bulletin, vol. 40, pp. 1397-1412.

Fink C., A. Mattoo and I. C. Neagu (2005). Assessing the Impact of Communication Costs on International Trade. Journal of International Economics, vol. 67(2), pp. 428-445.

Friedt, F. and Wilson W. (2018). Trade, Transport Costs and Trade Imbalances: An Empirical Examination of International Markets and 


\title{
Scientific Journal for Financial and Commercial Studies and Researches
}

\author{
Dr. Khaled El-Sakty and Dr. Ahmed Ezzat
}

Backhauls. Political Economy - Development: Domestic Development Strategies eJournal.

Grainger, A., Huiden, R., Rukanova, B. and Tan, Y. (2018). What is the cost of customs and borders across the supply chain? ... and how to mitigate the cost through better coordination and data sharing. World Customs Journal, vol. 12(2), pp. 3-30.

Hausman W. H., H. L. Lee and U. Subramanian (2013). The impact of logistics performance on trade. Production and Operations Management, vol. 22(2), pp. 236-252.

Heilig L, Schwarze S and S. Voß (2017). Digital transformation in maritime ports: analysis and a game theoretic framework. Netnomics, vol. 18, pp. $227-254$.

Hummels D. (2007) Transportation Costs and International Trade in the Second Era of Globalization, Journal of Economic Perspectives, American Economic Association, vol. 21(3), pp. 131-154, Summer.

ICTE ToL 2019: ICTE in Transportation and Logistics 2019

Kiran and Singh A. (2016) Service Quality Models: A Gap Study, Business and Economic Research, vol. 6, No. 1. https://doi.org/10.5296/ber.v6i1.9636

Kleinert J. and J. Spies (2011). Endogenous transport costs in international trade. Technical report, IAW Discussion Papers No. $74 \mathrm{~J}$.

Lakshmanan T. (2011). The broader economic consequences of transport infrastructure investments. Journal of Transport Geography, vol. 19(1):112 
Scientific Journal for Financial and Commercial Studies and Researches

Dr. Khaled El-Sakty and Dr. Ahmed Ezzat

Lun Y. V., J. Carlton, K. Bichou (2016). Examining the economic impact of transport complex economies. Journal of Shipping and Trade, vol. 1(1):117

Meng Y. (2011). Effects of Information and Communication Technology and Relationship Network on International Trade. In: Tan H., Zhou M. (eds) Advances in Information Technology and Education. Communications in Computer and Information Science, vol 201. Springer, Berlin, Heidelberg. https://doi.org/10.1007/978-3-642-22418-8_77

Munim Z. H. and H-J Schramm (2018). The impacts of port infrastructure and logistics performance on economic growth: the mediating role of seaborne trade. Journal of Shipping and Trade, vol. 3, No. 1.

Nath, K.H. and L. Liu (2017). Information and Communications Technology (ICT) and Services Trade. Information Economics and Policy, vol. 41.

Sadikov A. (2008). Border and Behind-The-Border Trade Barriers and Country Exports. IMF Working Papers, no. 07 (292).

SRM and Alex Bank (2018). The Suez Canal after the expansion. Analysis of the traffic, competitiveness indicators, the challenges of the BRI and the role of the Free Zone. Naples, Permanent Observatory on Maritime Transports and Logistics.

SRM and Alex Bank (2015). The new Suez Canal: economic impact on Mediterranean maritime trade. Naples, Permanent Observatory on Maritime Transports and Logistics.

Suez Canal Authority (2019). Suez Canal Traffic Statistics: Annual Report 2019. Planning \& Research Department - Information Center. 
Scientific Journal for Financial and Commercial Studies and Researches

Dr. Khaled El-Sakty and Dr. Ahmed Ezzat

Tijan, E., A. Agatic, M. Jovic, S. Aksentijevic (2019). Maritime National Single Window-A Prerequisite for Sustainable Seaport Business. Sustainability, vol. 11, 4570.

Thai, V. V. (2008). Service Quality In Maritime Transport: Conceptual Model And Empirical Evidence. Asia Pacific Journal Of Marketing And Logistics, vol. 20(4), Pp. 493-518.

Thiemann, F., E. M. Fleming and R. A. E. Mueller (2012). Impact of information and communication technology (ICT) on international trade in fruit and vegetables: A gravity model approach. 2012 Conference, August 18-24, 2012, Foz do Iguacu, Brazil 123839, International Association of Agricultural Economists.

UNCTAD (2013). Maritime Connectivity and Trade. Policy Issues in International Trade and Commodities, Study Series No. 70. New York and Geneva.

UNCTAD (2018). Review of Maritime Transport 2018. United Nations publication. Sales No. E.18.II.D.5. New York and Geneva.

UNCTAD (2019). Review of Maritime Transport 2019. United Nations publication. Sales No. E.19.II.D.20. New York and Geneva.

Wilmsmeier G. and J. Hoffmann (2008). Liner Shipping Connectivity and Port Infrastructure as Determinants of Freight Rates in the Caribbean. Maritime Economics and Logistics, vol. 10. Pp. 130-151. 
Scientific Journal for Financial and Commercial Studies and Researches

Dr. Khaled El-Sakty and Dr. Ahmed Ezzat

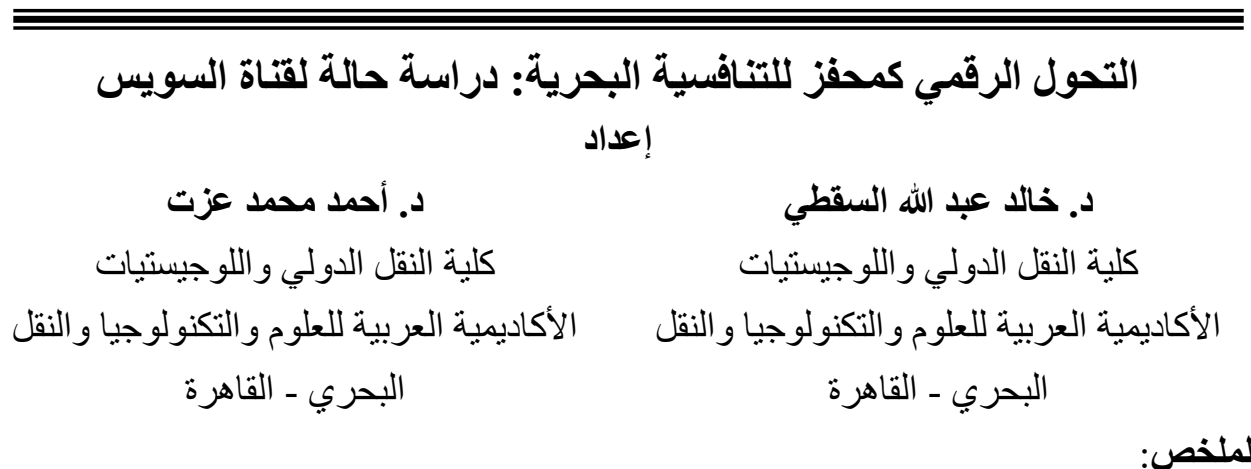

أصبح التحول الرقمي من أهم القضايا التي تشغل عالم الأعمال في ظل قدرت على إحداث نأثيرات

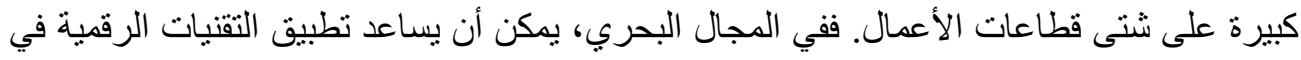
تحقيق أهداف الاستدامة واكتساب ميزة تنافسية من خلال تقليل التكاليف وتعزيز الكفاءة الكاءئ وحماية البيئة.

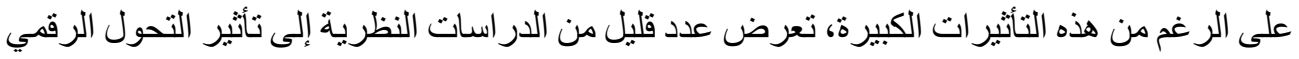
على القدرة التنافسية البحرية. تتعرض هذه الدراسة إلى تحديد القنوات التي يؤثر من خلالها التحول

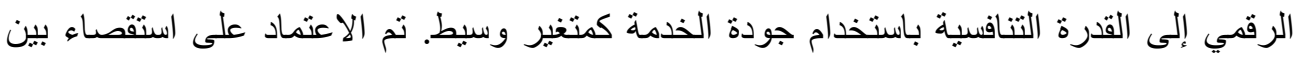

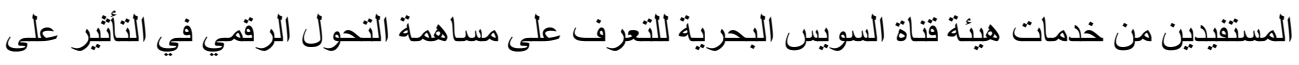

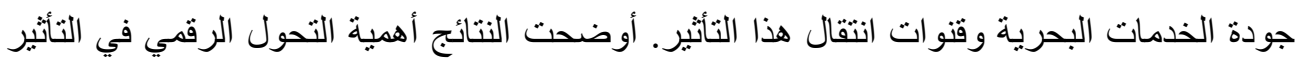
على القدرة التنافسية البحرية في قناة السويس من خلال التأثير على العمليات و الإدارة ونتائج الأعمال

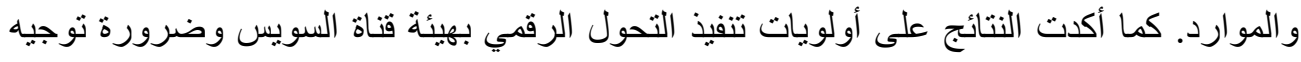

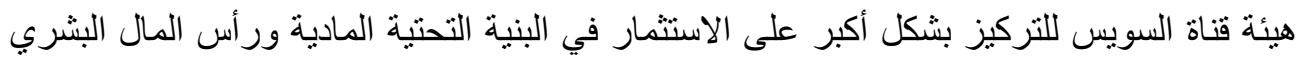

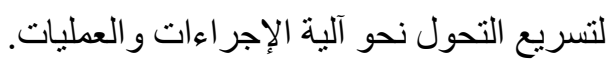

الكلمات الدالة: التنافسية البحرية ـ التحول الرقمي ـ النقل البحري ـ جودة الخدمات البحرية ـ قناة السويس 